Discussion Paper No. 14-080

\title{
Youth Unemployment in the OECD: The Role of Institutions
}

Andreas Sachs and Werner Smolny

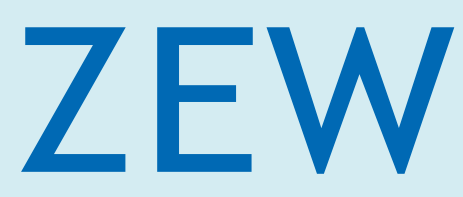

Zentrum für Europäische Wirtschaftsforschung $\mathrm{GmbH}$ Centre for European Economic Research 
Discussion Paper No. 14-080

\title{
Youth Unemployment in the OECD: The Role of Institutions
}

\author{
Andreas Sachs and Werner Smolny
}

Download this ZEW Discussion Paper from our ftp server:

http://ftp.zew.de/pub/zew-docs/dp/dp14080.pdf

Die Discussion Papers dienen einer möglichst schnellen Verbreitung von neueren Forschungsarbeiten des ZEW. Die Beiträge liegen in alleiniger Verantwortung der Autoren und stellen nicht notwendigerweise die Meinung des ZEW dar.

Discussion Papers are intended to make results of ZEW research promptly available to other economists in order to encourage discussion and suggestions for revisions. The authors are solely responsible for the contents which do not necessarily represent the opinion of the ZEW. 


\title{
Youth Unemployment in the OECD: The Role of Institutions
}

\author{
Andreas Sachs* Werner Smolny ${ }^{\dagger}$
}

\begin{abstract}
This paper analyzes the role of labor market institutions for youth unemployment, as contrasted to total unemployment. The empirical results are basically consistent with an insider view of labor market institutions. Labor market institutions tend to protect (older) employees but might harm (young) entrants. Remarkable is especially the significant and very high effect of employment protection for regular jobs on youth unemployment. In addition, the combined effects of powerful unions and a coordinated wage bargaining system are beneficial for older people and detrimental to youth. Finally, the paper establishes significant labor supply effects and effects of the education system on youth and total unemployment.
\end{abstract}

JEL classification: E02, E24, J21, J68

Keywords: Youth unemployment, labor market institutions, age-specific unemployment

${ }^{*}$ Centre for European Economic Research (ZEW), P.O. Box 103443, D-68034 Mannheim, Germany, Phone: +49/621/1235-145, Fax: +49/621/1235-223, E-mail: sachs@zew.de

${ }^{\dagger}$ University of Ulm, D-89081 Ulm, Germany, Phone: +49/731/50-24261, Fax: +49/731/50-24262, E-mail: werner.smolny@uni-ulm.de 


\section{Introduction}

In the aftermath of the recent financial crisis, unemployment increased to rates of more than 20 percent in some European countries. Youth unemployment soared to rates of more than 40 or 50 percent. On the one hand, this poor labor market outcome is driven by cyclical factors and the general economic conditions. On the other hand, there is a large literature which highlights the role of labor market institutions for unemployment. For instance, the generosity of the benefit system or the strictness of employment protection regulations are blamed for the magnitude and persistence of unemployment. In addition, some countries perform much better than others, both in terms of total unemployment as well as in terms of youth unemployment.

The main contribution of our paper is the macroeconomic analysis of the effects of labor market institutions on youth unemployment, i.e. people aged 15 to 24 , as contrasted to total unemployment or unemployment of people above 25. Firstly, unemployment of youth is an especially important economic policy problem, since phases of unemployment in the early labor market career are supposed to leave persistent scars and reduce earnings and employability over the entire life cycle (see, for example, Gregg (2008)). Secondly, the analysis of youth unemployment, as contrasted to unemployment of older people can yield more information on the impact of institutions on unemployment in general.

One basic aspect of the literature on the effect of institutions on unemployment is the inconclusiveness of especially the empirical results (see, for instance, Howell et al. (2007)). The analysis of age-specific unemployment provides several advantages. Most important are structural differences between youth and older people in the labor market. Youth can be interpreted to some extent as entrants, who often have to find their first job and have to gain job experience and job-specific human capital. Older people, in contrast, consist mainly of employees with job experience and tenure. It should therefore be expected that some labor market institutions affect youth and older people differently. One important example are employment protection regulations. On the one hand, those regulations protect (older) employees, typically according to tenure. On the other hand, Breen (2005) points out that it hinders the labor market entry of (young) entrants. The overall effect of employment protection on unemployment might be small or difficult to estimate, but the differentiating effect on youth and older people can give more information on the impact of those regulations in general.

The advantage of the macroeconometric approach is that it allows cross-country and timeseries analyses of general aspects of the institutional framework. The empirical analysis is based on a panel of 17 OECD countries with annual data from 1982 to 2005 . The data on institutions include indicators from five areas, i.e. tax system, bargaining system, employment protection, unemployment benefits, and product market regulation. We test, in addition, for demographic effects (the share of youth in the total population) and include an indicator of the education system (the share of the youth labor force in the youth population). The first indicator 
relates to the relative size of the entrants cohort and should capture labor supply effects. The second variable is an indicator for the labor market association of the schooling system. The role of the education system for youth unemployment is intensely studied in microeconometric analyses. The contribution of our paper is the macroeconomic cross-country and time-series analyses of the education system and demographics, in combination with other labor market institutions.

From the methodological side, a Bayesian estimator is employed which takes model uncertainty into account. The empirical analysis of the impact of institutions on unemployment is difficult, since a large number of indicators is available, and theoretical arguments provide only limited support regarding the specification of the model. The Bayesian model averaging approach (Sala-i-Martin et al. (2004)) permits to test systematically for the relevance of a large number of explanatory variables within small data sets. The estimates yield inclusion probabilities for each of the variables.

Section 2 gives a short review of the literature on the effects of institutions on unemployment, with a focus on youth unemployment. Section 3 discusses the data and the methodological approach. Section 4 presents the estimation results, and section 5 discusses the robustness of the findings. The final section concludes.

\section{Literature}

\subsection{Institutions and Unemployment}

Over the last two or three decades, a plethora of theoretical and empirical contributions focused on various labor market institutions to explain why labor market performance differs both over time as well as across countries. From a theoretical point of view, labor market institutions influence the behaviour of either the labor demand and/or the labor supply side, thus affecting hiring and wage-setting decisions (see Nickell and Layard (1999)). With the development of internationally comparable data, factors like the unemployment benefit system, employment protection or the labor tax system have moved at centre stage of empirical macroeconomic studies searching for sources of cross-country differences in labor market performance. Most of these studies focus on unemployment as the target variable since it is well-suited to reflect an economy's ability to avoid involuntary joblessness.

Theoretical predictions on the link between a labor market institution and unemployment are partially ambiguous. For example, a generous unemployment benefit system lifts the unemployed's reservation wage, but can improve the job match quality (Holmlund (1998), Acemoglu and Shimer (2000)). Further, the coverage and the duration of unemployment benefits can also substantially affect the macroeconomic impact on unemployment. A high level of employment protection is expected to lower both hirings and firings, and it is unclear which effect prevails 
(Ljungqvist (2002)). More recently, the distinction between employment protection for permanent and for temporary contracts as well as the interplay between both aspects has gained attention (see, for instance, Boeri and Garibaldi (2007) or Bentolila et al. (2012)). Similarly, powerful unions can either negotiate such that the income of insiders is maximized, or that aggregate unemployment is minimized. This also partially depends on the level of bargaining coordination, that is the informal or formal coordination of the bargaining process.

Empirical studies try to sort out which theories are most appropriate by estimating panel data models which explain unemployment by various labor market institutions and a set of control factors. Earlier studies tend to find a detrimental impact of labor market regulation (for instance Scarpetta (1996), Nickell (1997) or Blanchard and Wolfers (2000)). More recent contributions build upon advances in both data quality and availability as well as methodology, and draw a less clear-cut picture on the influence of labor market regulation on unemployment. By using different specifications and estimators to check the robustness of this link, Baccaro and Rei (2007) state that only union density and unemployment exhibit a robust and significant positive correlation. Similarly, the significance of the findings of Bassanini and Duval (2006) depend to some extend on the chosen specification. In order to ensure robustness, Sachs (2012) applies a model averaging approach and pins down six institutional factors as significantly linked to the evolution of unemployment. A summary of the relevant literature is given in Arpaia and Mourre (2012).

\subsection{Institutions and Youth Unemployment}

Much less macroeconometric contributions have dealt with the relation between labor market institutions and different groups of unemployed. From a theoretical point of view, groups divided by age, sex, qualification or migration status exhibit differences in their labor market status or their labor supply decisions (Bertola et al. (2007)). Due to these differences, a change in labor market regulation can affect groups differently.

For instance, strengthening employment protection or establishing a minimum wage will probably favour older workers with permanent contracts and job experience over younger ones who will be blocked out of the labor market. This depressing effect of minimum wages on the opportunity to gain job experience is highlighted by Gorry (2013). Accordingly, Neumark and Wascher (2004) find that minimum wages reduce the employment rate of the youth population more than of the prime-age population. Regarding job protection, Jimeno and RodriguezPalenzuela (2002) argue that young workers have, on average, a lower productivity than older workers. If strict employment protection leads to high firing costs (through severance payments, for instance), less productive young workers become unattractive for employers. However, job protection for temporary contracts can have a different effect since flexible temporary job contracts could lead to high transition rates between employment and unemployment (Blanchard and Landier (2002)), and to a crowding out of regular jobs for temporary ones (Kahn 
(2010)). This interplay between employment protection for fixed-term and open-ended contracts is also highlighted by Centeno and Novo (2012) who emphasize the substitutability between both types of contracts. More concretely, increasing protection for permanent contracts raises the relevance of fixed-term contracts for employment adjustments. Given that youth workers more often have fixed-term contracts they are affected more by changes in the level of employment protection. Finally, Bertola et al. (2007) report significant differences in the reaction of youth and prime-aged population rates to changes in the union bargaining power. More specifically, increasing unionization reduces employment rates of the youth population more strongly than employment rates of the prime-aged population.

Breen (2005) focuses on the quality of the educational system to explain cross-country variation in youth unemployment. He concludes that a strong educational system which supports the integration of the youth population in the labor market can generally help to reduce unemployment by avoiding periods of youth joblessness. A comprehensive analysis of the advantages of vocational training systems, or in general combined school-workplace education is given by Biavaschi et al. (2012). Lopez-Mayan and Nicodemo (2012) find that apprenticeship training reduces the time of finding the first job in Spain. Mohrenweiser and Zwick (2009) discuss the costs and benefits of apprenticeship training for firms in Germany. Finally, Korenman and Neumark (2000) emphasize the role of demographic trends for youth unemployment. More concretely, a larger share of youth population to prime-age population pushes youth labor supply, leading to higher youth unemployment rates given that youth and prime-aged persons are not perfect substitutes in production.

\section{Empirical Specification}

We make use of a comprehensive data set on different aspects of labor market regulation, demographic developments, and on the quality of the educational system. We further apply a model averaging approach in order to circumvent the risk of model uncertainty, and to ensure robustness of the findings.

\subsection{Data}

We use an unbalanced panel data set for 17 OECD countries from 1982 to $2005 .^{1}$ The dependent variables are the total unemployment rate, the youth unemployment rate (15-24) measured as the share of youth unemployed to the youth labor force, and the unemployment rate of the older population $(25+)$ measured as the share of unemployed $(25+)$ to the labor force $(25+)$.

\footnotetext{
${ }^{1}$ We cannot use more recent data due to to a structural break in the replacement rate data. More specifically, the OECD provides new measures for the replacement rate since 2001 which are not comparable to the historical time-series we use in this paper.
} 
Data on age-specific unemployment are taken from the ILO. For the selection of labor market regulation variables we follow Sachs (2012). More specifically, we use indicators of five categories of regulation: the labor tax system, employment protection, the unemployment benefit system, and the wage bargaining system. We consider product market regulation as an additional relevant category as indicators of this category proved to be relevant for unemployment (Feldmann (2008)). As described in section 2, demographic developments as well as the quality of the educational system matter for unemployment. In total, we include 12 regulatory indicators, a demographic factor and an educational variable. We assign these 14 indicators to the group called Institutions. The specific indicators are briefly described in the following and more extensively in the Appendix.

The labor tax system is represented by the average values of the payroll, the income and the consumption tax. Wage bargaining is captured by three indicators, the union coverage (the share of workers affected by union wage agreements to all workers), bargaining coordination (the level at which bargaining formally or informally takes place), and union density (the share of workers organized in unions to all workers). The unemployment benefit system is represented by two indicators. More specifically, the replacement rate during the first year of unemployment captures the generosity of the unemployment benefit system. We also use the share of unemployed entitled to unemployment benefits to control for the coverage of the unemployment benefit system. Two additional institutional indicators are considered: First, a minimum wage indicator is taken into account which describes the level at which a minimum wage is set (the indicator from 0 indicating no minimum wage to 8 indicating that the minimum wage is set by the government). Second, an indicator for the level of product market regulation is included.

The degree of employment protection for regular and temporary employment represent the job protection system. More concretely, the former comprises information on severance payments, notice periods, notification procedures, the length of the trial period or the compensation following an unfair dismissal. The latter indicator covers information like the maximum number of fixed-term contracts that can be concluded successively, or whether employees from temporary work agencies and regularly employed workers are treated equally by regulation. These job protection variables are expected to capture the degree of labor market flexibility and the labor market access for entrants which probably affect youth and older workers differently according to their respective job experience.

Finally, a demographic factor is created by calculating the share of the youth population in the total population. This indicator relates to the relative size of the entrants cohort and should capture labor supply effects. The characteristics of the education system are more difficult to display as they are not directly observable. We use the share of the youth labor force in the youth population as one easily measurable indicator. It largely correlates to the relevance of combined school-workplace education which is expected to facilitate the transition into work. 


\subsection{Econometric Model}

Panel data allows to exploit both variation across countries as well as over time. The basic model reads

$$
U_{c, t, z}=\beta \text { Institutions } s_{c, t}+\delta \text { Controls }_{c, t}+\varepsilon_{c, t, z}
$$

$U_{c, t, z}$ is either total unemployment, youth unemployment (15-24) or unemployment (25+) in country $c$ for time $t$, where $z$ refers to the specific group of unemployed. We explain the dependent variable by the 14 indicators belonging to the group Institutions as explained in the data section, and some control factors. More concretely, we follow Nickell et al. (2005) and include the real interest rate, a productivity shock, a labor demand shock, and an import price shock in order to control for cyclical fluctuations. The construction of these shocks is described extensively in the Appendix. We also include an indicator capturing credit constraints since this appears to be a highly relevant factor for unemployment (Dromel et al. (2010)). We further make use of the panel structure of our data and control for unobserved heterogeneity by including time- and country-specific fixed effects.

The model described in equation (1) is generally well-suited to reveal significant correlations between institutions and unemployment. However, it might be prone to endogeneity resulting from omitted variables or reverse causality. It is impossible to consider all aspects which can influence unemployment in our model. However, the inclusion of fixed effects at least controls for any time-invariant idiosyncratic factor as well as for common shocks which affect all countries in the sample. Reverse causality could emerge when changes in unemployment cause changes in institutions. A government could be forced to implement labor market reforms when unemployment is particularly high. This issue is, to some extent, covered by the inclusion of fixed effects, as well. Nevertheless, a causal impact of a change in unemployment on an institutional change is less likely but still possible in our setup. Instrumental variable estimation would help but it is hard to find suitable instruments for institutions. Lagged values are probably a function of expected unemployment and are therefore inadequate instruments. Similarly, political, demographic or macroeconomic factors which have been used as instruments (Amable et al. (2011)) are likely correlated with both institutions and unemployment. Hence, we abstain to apply an instrumental variable estimator and interpret our findings as correlations, not as causal effects.

Theory provides only limited support regarding the specification of the model. More specifically, we do not know a priori which institutional indicators should be included in the model. It appears straightforward to estimate (1) with all institutional indicators. If the number of observations is sufficient, such an approach is appropriate to determine the impact of institutional factors on unemployment. However, if degrees of freedom are restricted caused by a limited number of observations, or if explanatory factors are highly correlated, as in our case, 
a misspecified model could result in misleading inference.

In order to explicitly control for model uncertainty, we apply a Bayesian model averaging approach following Sala-i-Martin et al. (2004). The basic idea of this method is to estimate and systematically evaluate variants of the basic model described in equation (1). More specifically, we estimate and evaluate all models which only differ in the combination of $k \epsilon K$ indicators (where $K=14$ ) included in Institution $s_{c, t}$. In contrast, the set of control variables as well as the country- and time-specific fixed effects are considered in all models. The consideration of models consisting of all possible combinations of the 14 institutional variables sums up to $2^{K}=16384$ models estimated. The evaluation of the models is carried out on the basis of model weights, whereby models with a better fit receive a higher weight. The weight of a specific model $M_{i}$ is calculated as

$$
P\left(M_{i} \mid \Delta\right)=\frac{p\left(M_{i}\right)\left(\sum_{c=1}^{N} T_{c}\right)^{-k_{i} / 2} S S E_{i}^{-\left(\sum_{i=c}^{N} T_{c}\right) / 2}}{\sum_{j=1}^{2^{K}} p\left(M_{j}\right)\left(\sum_{c=1}^{N} T_{c}\right)^{-k_{j} / 2} S S E_{j}^{-\left(\sum_{c=1}^{N} T_{c}\right) / 2}}
$$

$\mathrm{N}$ is the number of cross-sections and $T_{c}$ is the number of time-series observations for country $c$ (this extension to unbalanced panels is provided by Moral-Benito (2012)). Furthermore, $k_{i}$ is equal to the number of indicators contained in Institutions $s_{c, t}$ in model $i . p\left(M_{i}\right)$ is the prior model probability, and $S S E_{i}$ is the sum of squared residuals of model $i$. The prior model probability is given by

$$
p\left(M_{i}\right)=\left(\frac{\bar{k}}{K}\right)^{k_{i}}\left(1-\frac{\bar{k}}{K}\right)^{K-k_{i}}
$$

where $\bar{k}$ is the a priori specified model size, $k_{i}$ the number of indicators contained in Institutions $s_{i, t}$ for a specific model, and $K$ the total number of indicators which can be included in Institutions $s_{i, t}$, i.e. $K=14$. In the empirical application, we set the prior model size $\bar{k}$ to 6 , but provide results with prior model size values of 2 and 10 as a robustness check.

$P\left(M_{i} \mid \Delta\right)$ gives a measure for the quality of model $M_{i}$ in comparison to all $2^{K}$ considered models. A statement about the significance of the $K$ explanatory variables can now be calculated. Suppose that one is interested in a variable $x$. Summing up the model weights (following equation (2)) of all models containing $x$ gives the posterior inclusion probability. This measures the importance of the variable $x$ for explaining the dependent variable. If the corresponding variable is often included in models with higher quality, the posterior inclusion probability of $x$ is comparably large. In order to derive statements about the significance of a variable, the posterior inclusion probability needs to be set in relation to the prior inclusion probability which serves as a threshold dividing significant from insignificant variables. The prior inclusion probability is just $\frac{\bar{k}}{K}$ and thus depends on the prior model size. In the empirical application, a posterior inclusion probability value above the respective prior inclusion probability indicates 
significance of the corresponding variable.

Furthermore, the model weights can be used to derive a posterior mean and a posterior variance for each of the $K$ indicators.

$$
\begin{gathered}
E(\beta \mid y)=\sum_{j=1}^{2^{K}} P\left(M_{j} \mid y\right) \widehat{\beta_{j}} \\
\operatorname{VAR}(\beta \mid y)=\sum_{j=1}^{2^{K}} P\left(M_{j} \mid y\right) \operatorname{Var}\left(\beta \mid y, M_{j}\right)+\sum_{j=1}^{2^{K}} P\left(M_{j} \mid y\right)\left(\widehat{\beta}_{j}-E(\beta \mid y)\right)^{2}
\end{gathered}
$$

where $\widehat{\beta_{j}}=E\left(\beta \mid y, M_{j}\right)$ is the estimate of $\beta$ for model $j$. In other words, equation (4) gives the sum of the weighted coefficients $\beta$ over all models $j$. (5) measures the variance of coefficient $\beta$ as the sum of the estimation risk within a model $j$ (first term) and the variation of the coefficients across all models $j$ (second term).

\section{Results}

Table 1 depicts the results for the total unemployment rate. A prior model size $\bar{k}=6$ is chosen which corresponds to a prior inclusion probability of 0.43 . We focus on the 14 indicators referring to different areas, i.e. the tax system, the bargaining system, unemployment benefits, general regulation, employment protection, demography and education system. Results for the control variables are not shown. Column (1) reports the posterior inclusion probability, i.e. the estimated probability that those indicator should be included into the model. A posterior above the prior inclusion probability indicates significance. Column (2) reports the weighted mean of the estimated coefficients and column (3) the corresponding standard deviation according to equations (4) and (5). The results in Table 1 can serve as a reference point for the discussion of the corresponding effects for the age groups.

The tax system is taken into account with three indicators, i.e. the payroll tax, the consumption tax and the income tax. The results reveal that the payroll tax increases the unemployment rate while the consumption tax reduces it. The income tax is not significant, i.e. it must not be taken into the empirical model (the estimated posterior inclusion probability is less than the prior inclusion probability). The result is basically in accordance with theoretical arguments. The overall tax rate is less important for unemployment, but it matters how taxes are collected. Taxes that are based on employment are more harmful for employment. A corresponding result for the relevance of the type of taxes is revealed in Blanchard (2006).

The bargaining system is captured with three variables, union coverage, bargaining coordination and union density. The estimation results reveal that union coverage tends to increase 
Table 1: Results for total unemployment

\begin{tabular}{lccc}
\hline \hline Prior inclusion probability & & 0.43 & $(\bar{k}=6)$ \\
\hline Variable & $\begin{array}{c}\text { Posterior } \\
\text { inclusion } \\
\text { probability }\end{array}$ & $\begin{array}{c}\text { Posterior } \\
\text { mean }\end{array}$ & $\begin{array}{c}\text { Posterior } \\
\text { standard } \\
\text { deviation }\end{array}$ \\
& $(1)$ & $(2)$ & $(3)$ \\
\hline Payroll tax & 0.999 & 0.259 & 0.043 \\
Income tax & 0.048 & 0.002 & 0.018 \\
Consumption tax & 0.999 & -0.283 & 0.051 \\
Union coverage & 0.999 & 0.082 & 0.017 \\
Bargaining coordination & 0.996 & -0.516 & 0.127 \\
Union density & 0.040 & 0.001 & 0.007 \\
First year benefits & 0.975 & 0.043 & 0.014 \\
Benefit coverage & 0.048 & -0.018 & 0.140 \\
Minimum wage & 0.113 & -0.013 & 0.045 \\
Product market regulation & 0.043 & -0.005 & 0.051 \\
EPL regular & 0.998 & 1.867 & 0.435 \\
EPL temporary & 0.998 & -0.641 & 0.150 \\
Demography & 0.999 & 0.604 & 0.100 \\
Education & 0.999 & -0.097 & 0.020 \\
\end{tabular}

The dependent variable is the total unemployment rate. The shock variables (labor demand shock, productivity shock, real import price shock and the interest rate) as well as the credit constraints are included in each regression. We use an unbalanced panel for 17 countries from 1982 to 2005 and control for country- and time-specific fixed effects.

unemployment and the degree of bargaining coordination reduces it. Union density is not significant. This result is in line with the review of Aidt and Tzannatos (2008), where coordination is predominantly negatively related to unemployment. Union density is insignificant in the majority of the studies. Recent evidence also highlights the adverse role of union coverage for unemployment (Baker et al., 2005, and Sachs (2012)).

A third group of indicators is related to unemployment benefits. The results show that first year benefits tend to increase the unemployment rate, benefit coverage is not significant. In addition, the indicators for minimum wages and the degree of product market regulation do not show up significantly in the estimates.

A central institutional regulation is employment protection. It is taken into account with two variables, employment protection (EPL) for regular jobs and employment protection for temporary jobs. The results show that employment protection for regular jobs is associated with higher unemployment, while employment protection for temporary jobs is associated with lower unemployment rates. This finding is in line with the literature which emphasizes that a certain degree of job protection for temporary employment can be beneficial while job pro- 
tection for regular jobs is more likely to exhibit a detrimental impact on the labor market (see Blanchard and Landier (2002) for the detrimental labor market impact of flexible job protection for temporary contracts). The different signs for the two variables indicate that they capture different aspects of employment protection legislation. The first variable captures regular jobs, and it can be argued that a high degree of employment regulation tends to displace regular jobs in favor of temporary jobs, with an implied increase of fluctuations and frictional unemployment. Employment protection for temporary jobs might impede this effect.

Finally, the estimates include two variables which should matter especially for youth unemployment, the relative size of the youth cohort and the labor market association of the education system. The estimates reveal that both variables should clearly be included for the total unemployment rate as well. A large share of youth (age group 15-24) in the total population is associated with a higher total unemployment rate, i.e. demographic or labor supply effects are relevant for unemployment. In addition, the education system matters as well. Similar to the findings of Breen (2005), a larger share of the youth labor force in the youth population is associated with a smaller unemployment rate. Education systems which are closely connected to the labor market are associated with lower unemployment.

In general, the results for the total unemployment rate reveal that institutions matter for unemployment. The Bayesian estimator appears to be able to pick up relevant effects. Note that this estimator permits to include and test for the relevance of a large number of explanatory variables within the model, and it tends to yield more robust results in case of multicollinearity. However, one should hold in mind that the estimates can only yield significant effects, if there is useful variance in the data.

Table 2 presents the results for the age groups, i.e. for people aged 15-24 and 25+. In general the results for both groups are similar to each other, and they are similar to those for the total unemployment rate. We will concentrate the discussion on the most remarkable differences. Starting with the tax system, the payroll tax exhibits a positive sign, and the consumption tax shows up negatively. The quantitative effect is larger for youth, but one should hold in mind that the mean and the variance of youth unemployment rates are larger as compared with those of persons $25+$.

With respect to the bargaining system, union coverage increases unemployment. The effect is larger for youth and less significant for the age group 25+. Hence, we conclude that union policy is in particular detrimental for young outsiders. This result is in line with microeconomic evidence that unions mainly support insiders (see, for instance, Bentolila et al. (2012) for Spain or Kretsos (2011) for Greece). Bargaining coordination, on the other hand, tends to reduce unemployment. The effect is very important for the older age group, but not significant for youth. Both effects on collective bargaining combined indicate that especially youth are harmed while older people might gain.

The results for unemployment benefits reveal a high relevance of first year benefits for per- 
Table 2: Results for age-specific unemployment

\begin{tabular}{|c|c|c|c|c|c|c|}
\hline inclusion & & & 0.43 & $(\bar{k}=6)$ & & \\
\hline Age group & & $15-24$ & & & $25+$ & \\
\hline Variable & $\begin{array}{c}\text { Posterior } \\
\text { inclusion } \\
\text { probabil- } \\
\text { ity } \\
\text { (1) }\end{array}$ & $\begin{array}{c}\text { Posterior } \\
\text { mean } \\
\text { (2) }\end{array}$ & $\begin{array}{r}\text { Posterior } \\
\text { standard } \\
\text { deviation } \\
\text { (3) }\end{array}$ & $\begin{array}{c}\text { Posterior } \\
\text { inclusion } \\
\text { probabil- } \\
\text { ity } \\
\text { (1) }\end{array}$ & $\begin{array}{c}\text { Posterior } \\
\text { mean } \\
\text { (2) }\end{array}$ & $\begin{array}{r}\text { Posterior } \\
\text { standard } \\
\text { deviation } \\
\text { (3) }\end{array}$ \\
\hline Payroll tax & 0.999 & 0.550 & 0.082 & 0.999 & 0.181 & 0.037 \\
\hline Income tax & 0.042 & 0.002 & 0.028 & 0.079 & 0.006 & 0.024 \\
\hline Consumption tax & 0.999 & -0.618 & 0.095 & 0.981 & -0.160 & 0.048 \\
\hline Union coverage & 0.999 & 0.163 & 0.032 & 0.874 & 0.041 & 0.020 \\
\hline Bargaining coord. & 0.313 & -0.162 & 0.273 & 0.999 & -0.486 & 0.109 \\
\hline Union density & 0.044 & -0.002 & 0.015 & 0.177 & 0.010 & 0.024 \\
\hline First year benefits & 0.121 & 0.004 & 0.015 & 0.999 & 0.053 & 0.010 \\
\hline Benefit coverage & 0.038 & 0.005 & 0.199 & 0.054 & -0.021 & 0.141 \\
\hline Minimum wage & 0.039 & -0.001 & 0.030 & 0.602 & -0.104 & 0.098 \\
\hline Product market reg. & 0.052 & -0.017 & 0.120 & 0.039 & 0.002 & 0.037 \\
\hline EPL regular & 0.999 & 5.454 & 0.828 & 0.057 & 0.019 & 0.119 \\
\hline EPL temporary & 0.999 & -1.306 & 0.287 & 0.999 & -0.572 & 0.124 \\
\hline Demography & 0.999 & 1.003 & 0.193 & 0.999 & 0.514 & 0.086 \\
\hline Education & 0.543 & -0.055 & 0.058 & 0.999 & -0.131 & 0.018 \\
\hline
\end{tabular}

The dependent variable is the total unemployment rate. The shock variables (labor demand shock, productivity shock, real import price shock and the interest rate) as well as the credit constraints are included in each regression. We use an unbalanced panel for 17 countries from 1982 to 2005 and control for country-and time-specific fixed effects.

sons $25+$ but not for youth. One might argue that for youth getting a job is most important, and not the amount of benefits. In addition, youth are typically less entitled for benefits. The empirical result for minimum wages (taken at face value) imply that older people gain from them. A possible explanation is that minimum wages protect (older) insiders from (younger) outsiders. However, the effect on $25+$ unemployment is only weakly significant, and a corresponding effect on youth unemployment is not revealed.

The most clear-cut differences between youth and $25+$ persons are related to the effects of employment protection for regular jobs. The estimates reveal a highly significant and very large effect for youth unemployment. The corresponding effect for $25+$ unemployment is not significant, and EPL regular is not a relevant variable of the model. This result give support for the assumption that employment protection favours insiders more than outsiders. For youth (entrants or outsiders) the negative effects clearly predominate, for older people (employed 
insiders) the positive and negative effects balance. Employment protection for temporary jobs exhibits a negative sign. Here the importance of the effects for youth and $25+$ hardly differ, but the magnitude of the effect for youth is larger.

Finally, demographic effects matter for both, youth and $25+$ unemployment rates. The estimated coefficient is larger for youth unemployment. However, one should hold in mind that (the variance of) youth unemployment is larger. With respect to the education system, there is again a favorable effect of systems which are closely connected to the labor market. Somewhat surprisingly, the effect is larger and more relevant for older people. One argument for smaller effects for youth is that pure schooling systems tend to hide youth unemployment.

\section{Robustness Checks}

In the following, we analyse the robustness of the findings by changing our preferred specification in five ways. First, we use a different definition of youth unemployment. Second, we split the group of unemployed in male and female persons. Third, we exclude the fixed effects from the specification. Fourth and fifth, estimations are carried out with alternative shock variable specifications as well variations in the prior model size (as described in section 3.2). In summary, only the exclusion of fixed effects affect the findings considerably while the other alterations have only a minor impact.

Up to now, we have defined unemployment as share of unemployed of a specific age-group to the labor force of the same age-group. However, the type of education system can have a substantial impact on the youth unemployment rate. Some countries like Germany have a dual education system where apprentices belong to the labor force. Other countries carry out education mostly in schools and students are not included in the labor force. On the one hand, the labor force is smaller in the former type of countries, on the other hand, the number of unemployed as well. We check whether the definition of youth unemployment has an impact on our findings by running the model given in equation (1) with the share of youth unemployed to youth population as the dependent variable. In doing so, we avoid that differences in the educational system influences the results. This alternative definition hardly affects the outcome. Coefficients become smaller and the education system is estimated with a reversed sign. Both findings are not surprising. First, the alternative definition of youth unemployment shows less variation within countries which explains the smaller coefficients of the right-hand variables. Second, the positive sign of the education variable shows that the size of the labor force is correlated with the number of unemployed.

It could also be argued that a panel data model which compares age-specific unemployment across countries should focus on male unemployment since female labor force participation is driven by country-specific institutions like family policies or working-time restrictions. Hence, 
we distinguish between age-specific male and female unemployment and run the model given in equation (1) for both groups for total, youth and adult unemployment as dependent variables. The findings reveal only minor differences between total, male and female unemployment (the results are provided in the Appendix). Specifically, minimum wages and employment protection for both regular and temporary employment are less relevant for female than for male adult unemployed. Furthermore, the income tax becomes highly significant for female adult unemployed while it remains insignificant for males. Finally, the education variable which is negatively correlated with total, youth and adult unemployment becomes insignificant for female youth unemployed. The remaining results are not influenced by the distinction between male and female unemployment.

Using fixed-effects in the estimations entails that level differences across countries are wiped out. Hence, estimation is based on changes from country-specific means for all variables, and significant institutional effects based on level differences across countries could be masked by country-specific fixed effects. Running estimations without fixed-effects indeed changes the significance of some institutional variables. For total unemployment as dependent variable and without fixed effects, union density, benefit coverage and product market regulation gain importance, while employment protection for regular employment and the education variable are now below the significance threshold. For youth unemployment, bargaining coordination, first year benefits, minimum wages and product market regulation become significant, while employment protection for regular employment as well as the education variable are no longer significant if fixed effects are excluded. However, we do not know whether the changes in the findings are caused by the omission of relevant time-invariant factors. Neglecting time-invariant differences in cultural, social or political aspects could spuriously attribute significance to institutional factors. Hence, we prefer the more sophisticated specification with fixed effects.

Excluding shocks marginally affects the findings. Bargaining coordination becomes significant for youth and adult unemployment, first year benefits becomes significant for youth employment. Similarly, substituting shocks by the output gap doesn't change much. For youth unemployment, bargaining coordination becomes clearly significant while first year benefits become just significant. For adult unemployment, the posterior inclusion probability for consumption taxes drop below the significance threshold. Finally, the model averaging has been carried out with a prior model size of 6 . As explained in section 3.2, this subjective choice can affect the findings through its impact on the prior model probability. Hence, we run the estimations with prior model sizes of 2 and 10. Only minor quantitative changes occur due to these alternative prior model sizes. 


\section{Conclusions}

The results presented here show that institutions matter, for total unemployment as well as for youth unemployment. In addition, different institutions affect youth and older people differently, and the differential effect on unemployment can contribute to the understanding of the working of institutions. In general, the estimation results are in accordance with an insider view of labor market institutions. Older people can be interpreted as insiders, youth can be interpreted as outsiders, and specific institutions protect insiders from outsiders.

Remarkable is especially the very high correlation of employment protection for regular jobs with youth unemployment; the corresponding correlation with total unemployment is much smaller and the correlation with $25+$ unemployment is not significant. From a theoretical point of view, employment protection exhibits countervailing effects on unemployment. On the one hand, it makes dismissing workers difficult; on the other hand, those constraints tend to reduce hirings. The results here indicate that for youth the detrimental effects clearly dominate, for older people positive and negative effects just balance.

A corresponding insider argumentation can also be applied for the differential effects of the bargaining system. Union coverage exhibits a strong detrimental effect on youth unemployment, the corresponding effect for older people is much smaller and less significant. In addition, bargaining coordination reduces unemployment more for older people as compared with youth. Both effects together imply that union activities protect older people and harm youth.

Finally, the consideration of youth unemployment introduces relevant new variables into the analysis. Firstly, it introduces a focus on demographic or labor supply effects. It appears reasonable that youth might face more difficulties finding jobs in periods of larger entrants cohorts. The empirical results here show that labor supply effects are relevant for older people as well. Secondly, the analysis of youth unemployment puts the education system at center stage. The results here indicate that education systems with a close connection to the labor market are associated with lower unemployment, for youth as well as for older people. However, our indicator is only a crude measure of the different aspects of the way of introducing youth to the labor market. Given the relevance of youth unemployment for economic policy and given the relevance of education on labor market success in general, a better understanding of those aspects should remain on the research agenda. 


\section{References}

Acemoglu, D. and R. Shimer (2000) "Productivity gains from unemployment insurance" European Economic Review 44, 1195-1224.

Aidt, T. and Z. Tzannatos (2008) "Trade unions, collective bargaining and macroeconomic performance: a review" Industrial Relations Journal 39, 258-295.

Amable, B., Demmou, L. and Gatti, D. (2011) "The effect of employment protection and product market regulation on labour market performance: substitution or complementarity?" $A p$ plied Economics 43, 449-464.

Arpaia, A. and Mourre, G. (2012) "Institutions and Performance in European Labour Markets: Taking a Fresh Look at Evidence" Journal of Economic Surveys 26, 1-41.

Baccaro, L. and D. Rei (2007) "Institutional determinants of unemployment in OECD countries: Does the deregulatory view hold water?" International Organization 61, 527-569.

Bassanini, A. and R. Duval (2006) "The determinants of unemployment across OECD countries: Reassessing the role of policies and institutions" OECD Economic Department Working Paper number 486.

Beck, T. and A. Demirgüç-Kunt (2009) "Financial Institutions and Markets Across Countries and over Time: The Updated Financial Development and Structure Database" World Bank Economic Review 24, 77-92.

Bentolila, S., J. Dolado and J. Jimeno (2012) "Reforming an insider-outsider labor market: the Spanish experience" IZA Journal of European Labour Studies 1, 1-29.

Bertola, G., F. Blau and L. Kahn (2007) "Labor market institutions and demographic employment patterns" Journal of Population Economics 20, 833-867.

Biavaschi, C., W. Eichhorst, C. Giulietti, M. Kendzia, A. Muravyev, J. Pieters, N. RodriguezPlanas, R. Schmidl, K. Zimmermann (2012) "Youth Unemployment and Vocational Training" IZA Discussion Paper No. 6890.

Blanchard, O. (2006) "European Unemployment: The Evolution of Facts and Ideas" Economic Policy 45, 5-59.

Blanchard, O. and A. Landier (2002) "The Perverse Effects of Partial Labour Market Reform: Fixed-Term Contracts In France" Economic Journal 112, F214-F244.

Blanchard, O. and Wolfers, J. (2000) "The Role of Shocks and Institutions in the Rise of European Unemployment: The Aggregate Evidence" Economic Journal 110, C1-C33. 
Boeri, T. and P. Garibaldi (2007) "Two Tier Reforms of Employment Protection: a Honeymoon Effect?" Economic Journal 117, F357-F385.

Breen, R. (2005) "Explaining Cross-national Variation in Youth Unemployment: Market and Institutional Factors" European Sociological Review 21, 125-134.

Centeno, M. and A. Novo (2012) "Excess worker turnover and fixed-term contracts: Causal evidence in a two-tier system" Labour Economics 19, 320-328.

Dromel, N., E. Kolakez and E. Lehmann (2010) "Credit Constraints and the Persistence of Unemployment" Labour Economics 17, 823-834.

Feldmann, H. (2008) "Business regulation and labor market performance around the world" Journal of Regulatory Economics 33 201-235.

Gorry, A. (2013) "Minimum wages and youth unemployment" European Economic Review 64, $57-75$.

Gregg, P. (2008) "The Impact of Youth Unemployment on Adult Unemployment in the NCDS" Economic Journal 111, F626-F653.

Holmlund, B. (1998) "Unemployment Insurance in Theory and Practice" Scandinavian Journal of Economics 100, 113-141.

Howell, D.R., D. Baker, A. Glyn, and J. Schmitt (2007) "Are protective labor market institutions at the root of unemployment? A critical Review of the Evidence" Capitalism and Society 2, 1-71.

Jimeno, J. and D. Rodriguez-Palenzuela (2002) "Youth Unemployment in the OECD: Demographic Shifts, Labour Market Institutions, and Macroeconomic Shocks" ECB Working Paper No. 155.

Kahn, L. (2010) "Employment protection reforms, employment and the incidence of temporary jobs in Europe: 1996-2001" Labour Economics 17, 1-15.

Korenman, S. and D. Neumark (2000) "Cohort Crowding and Youth Labor Markets: A CrossNational Analysis" in David G. Blanchflower and Richard B. Freeman (eds) Youth Employment and Joblessness in Advanced Countries, University of Chicago Press.

Kretsos, L. (2011) "Union responses to the rise of precarious youth employment in Greece" Industrial Relations Journal 42, 453-472.

Ljungqvist, L. (2002) "How Do Lay-Off Costs Affect Unemployment?" Economic Journal 112, 829-853. 
Lopez-Mayan, C. and C. Nicodemo (2012) "Vocational High School or Vocational College? Comparing the Transitions from School to Work" IZA Discussion Paper, No. 6309.

Mohrenweiser, J. and T. Zwick (2009) "Why Do Firms Train Apprentices? The Net Cost Puzzle Reconsidered" Labour Economics 16, 631-637.

Moral-Benito, E. (2012) "Determinants of Economic Growth: A Bayesian Panel Data Approach" Review of Economics and Statistics 94, 566-579.

Neumark, D. and W. Wascher (2004) "Minimum wages, labor market institutions, and youth unemployment: a cross-national analysis" Industrial and Labor Relations Review 57, 223248.

Nickell, W. (2006) "The CEP-OECD Institutions Data Set (1960-2004)" CEP Discussion Paper number 759. With data set: http://cep.lse.ac.uk/pubs/download/data0759.zip.

Nickell, S. (1997) "Unemployment and Labor Market Rigidities: Europe versus North America" Journal of Economic Perspectives 11, 55-74.

Nickell, S. and R. Layard (1999) "Labor Market Institutions and Economic Performance" in Handbook of Labour Economics 3 by O. Ashenfelter and D. Card, Eds., North Holland: Amsterdam, 3029-3083.

Nickell, S. and L. Nunziata (2001) "Labour Market Institutions Database" CEP Discussion Paper number 502.

Nickell, S., L. Nunziata and W. Ochel (2005) "Unemployment in the OECD since the 1960s. What do we know?" Economic Journal 115, 1-27.

Sala-i-Martin, X., G. Doppelhofer and R. Miller (2004) "Determinants of Long-Term Growth: A Bayesian Averaging of Classical Estimates (BACE) Approach" American Economic Review 94, 813-835.

Sachs, A. (2012) "What really drives unemployment? A bayesian approach to determine the impact of institutions on the unemployment rate" Economics Bulletin 32, 1008-1019.

Scarpetta, S, (1996) "Assessing the role of labour market policies and institutional settings on unemployment: a cross-country study" OECD Economic Studies no. 26.

Visser, J. (2009) "The ICTWSS Database: Database on Institutional Characteristics of Trade Unions, Wage Setting, State Intervention and Social Pacts in 34 countries between 1960 and 2007". 


\section{Appendix}

\section{Data}

All variables are on an annual basis and have been gathered for the period from 1982 to 2005 . The countries included in the analysis are Australia, Austria, Belgium, Canada, Denmark Finland, France, Germany, Italy, Japan, the Netherlands, Norway, Spain, Sweden, Switzerland, the United Kingdom, and the United States. The dependent variables in the empirical analysis are the total unemployment rate, the youth unemployment rate calculated as the share of unemployed aged 15-24 to the labor force aged 15-24, and the unemployment rate of persons aged $25+$ calculated as the share of unemployed aged $25+$ to the labor force aged $25+$. This data is taken from the ILO.

The taxes have been constructed according to the definition given in Nickell and Nunziata (2001). The payroll tax $t 1$ is calculated as $t 1=\frac{e s s}{i e-e s s}$ with ess equal to the employer's social security contributions and $i e$ equal to the compensation of employees. The income tax $t 2$ is $t 2=\frac{i t}{h c r}$ where $i t$ is the direct tax spending and hcr the household current receipt. Finally, the consumption tax $t 3$ is the result of $t 3=\frac{t l s}{f c e}$ with $t l s$ equal to taxes less subsidies on products and imports and $f c e$ equal to the final consumption expenditure of households.

The union coverage and union density as well as the bargaining coordination are indicators of the bargaining system and power and come from the Visser database (see Visser (2009)).

According to Nickell (2006), we construct the replacement rates for the first year of unemployment as an indicator for the unemployment benefit system. Furthermore, the Fondazione Rodolfo de Benedetti delivers data on unemployment benefit coverage. When data is missing, we assign the missing observations the same value as the first preceding or successive observation with a valid value. If both a preceding and successive value is available, the mean is constructed.

Data on product market regulation come from the OECD, as well. We use the regulation indicators in energy, transport and communication sectors (ETCR). This database delivers information on the barriers to entry and on public ownership.

The minimum wage indicator that ranges from 0 (no minimum wage) to 8 (national minimum wage set by the government) and is provided by Visser (2009). Note, that this indicator only makes a statement about the existence and the degree of government intervention. It does not contain information about the actual minimum wage level. Such information is not available for a sufficiently large share of our sample.

The employment protection legislation indicators for regular and temporary employment have been taken from the OECD labor statistics database. For regular employment, the classical information on severance payments, notice periods, and notification procedures are complemented by data like the length of the trial period or the compensation following an unfair 
dismissal. The employment protection indicator for temporary employment covers information like the maximum number of fixed-term contracts that can be concluded successively, or whether employees from temporary work agencies and regularly employed workers are treated equally by regulation. Both indicators range from 0 to 6 where the individual characteristics are weighted according to a rather complex system. The higher the employment protection value the higher the degree of protection of the respective type of contract.

The share of youth population aged 15-24 to total population is our preferred measure for demographic developments. In order to construct an indicator for the quality of the education system, we calculate the share of the youth labor force to youth population, both aged 15-24.

Concerning macroeconomic shocks, we closely follow the approach proposed by Nickell et al. (2005). The real import price is the import price deflator divided by the GDP deflator. According to the following equation, the shock is the log change of the real import price (IPS) times the import share in GDP IPS $=\frac{I m p o r t s}{G D P} \log \left(\frac{I P_{\text {deflator }}}{G D P_{\text {deflator }}}\right)$ with $I P_{\text {deflator }}$ being the import price deflator. The real interest rate is the long-term interest rate corrected for the current inflation rate. For the construction of the total factor productivity (TFP) shocks we follow Bassanini and Duval (2006) and calculate first the change in the log of TFP as $\Delta \ln (T F P)=$ $\frac{\Delta \ln (Y)-\alpha \Delta \ln (T E)+(1-\alpha) \Delta \ln (K)}{\alpha}$ with $Y$ equal to the GDP in the business sector, $T E$ is total employment, $K$ the gross capital stock, and $\alpha$ the share of labor income in total business sector income. Cumulating the changes in the log TFP's over years gives the TFP in each year. Finally, TFP trend deviations are taken to construct an index for TFP shocks by applying the HP-filter with a $\lambda$ of 100. The labor demand shock is the change in the residuals of a labor demand model to be estimated. Hence, we estimate the following equation for each country and take $\varepsilon$ as the country-specific labor demand shock $\ln \left(T E_{t}\right)=\beta_{0}+\sum_{i=1}^{3} \beta_{i} \ln \left(T E_{t-i}\right)+\beta_{4} \ln \left(Y_{t}\right)+\beta_{5} \ln \left(L C_{t}\right)+\varepsilon_{t}$. Again, $T E$ is total employment, $Y$ is the real GDP and $L C$ are the real labor costs per employee.

Finally, for the credit constraints we use data from Beck and Demirgüç-Kunt (2009). More specifically, the indicator for private credit by deposit money banks and other financial institutions over GDP is used.

In the following, some descriptive statistics are given including minimum and maximum values, mean and median as well as the standard deviation for the whole sample. 
Table 3: Descriptive statistics

\begin{tabular}{lccccc}
\hline \hline Variable & Min & Max & Mean & Median & S.D. \\
\hline Unemployment total & 1.59 & 23.88 & 7.55 & 7.16 & 3.92 \\
Unemployment 15-24 & 3.20 & 43.80 & 14.89 & 12.40 & 8.71 \\
Unemployment 25+ & 1.10 & 19.70 & 6.18 & 5.85 & 3.17 \\
Payroll tax & 0.00 & 32.36 & 13.42 & 13.73 & 8.87 \\
Income tax & 5.83 & 33.80 & 16.49 & 15.91 & 5.42 \\
Consumption tax & 1.61 & 33.53 & 19.34 & 20.44 & 6.54 \\
Union coverage & 13.70 & 99.00 & 67.90 & 75.00 & 24.81 \\
Bargaining coordination & 1.00 & 5.00 & 3.19 & 4.00 & 1.28 \\
Union density & 8.01 & 87.43 & 39.40 & 33.98 & 21.77 \\
First year benefits & 1.00 & 88.80 & 49.08 & 52.65 & 20.30 \\
Benefit coverage & 0.05 & 3.23 & 0.71 & 0.63 & 0.53 \\
Minimum wage & 0.00 & 8.00 & 3.50 & 2.00 & 2.86 \\
Product market regulation & 0.94 & 6.00 & 3.69 & 3.82 & 1.29 \\
EPL regular & 0.17 & 3.88 & 1.98 & 1.87 & 0.85 \\
EPL temporary & 0.25 & 5.38 & 2.15 & 1.88 & 1.44 \\
Demography & 10.32 & 19.42 & 14.19 & 13.97 & 1.96 \\
Education & 32.03 & 79.07 & 57.59 & 59.91 & 11.82 \\
\hline \hline
\end{tabular}


Table 4: Results for male and female total unemployment

\begin{tabular}{lccc|ccc}
\hline \hline Prior incl. probab. & \multicolumn{3}{c}{ male } & \multicolumn{3}{c}{ female } \\
\hline Variable & $\begin{array}{c}\text { Posterior } \\
\text { inclusion } \\
\text { probabil- } \\
\text { ity }\end{array}$ & $\begin{array}{c}\text { Posterior } \\
\text { mean }\end{array}$ & $\begin{array}{c}\text { Posterior } \\
\text { standard } \\
\text { deviation }\end{array}$ & $\begin{array}{c}\text { Posterior } \\
\text { inclusion } \\
\text { probabil- } \\
\text { ity } \\
\text { (1) }\end{array}$ & $\begin{array}{c}\text { Posterior } \\
\text { mean }\end{array}$ & $\begin{array}{c}\text { Posterior } \\
\text { standard } \\
\text { deviation }\end{array}$ \\
& & $(2)$ & $(3)$ & $(1)$ & $(2)$ & $(3)$ \\
\hline Payroll tax & 0.999 & 0.267 & 0.044 & 0.999 & 0.301 & 0.059 \\
Income tax & 0.097 & -0.009 & 0.035 & 0.912 & 0.259 & 0.114 \\
Consumption tax & 0.999 & -0.265 & 0.053 & 0.999 & -0.373 & 0.064 \\
Union coverage & 0.999 & 0.085 & 0.018 & 0.984 & 0.083 & 0.023 \\
Bargaining coord. & 0.968 & -0.459 & 0.153 & 0.990 & -0.577 & 0.158 \\
Union density & 0.073 & 0.003 & 0.014 & 0.064 & -0.003 & 0.014 \\
First year benefits & 0.981 & 0.047 & 0.014 & 0.410 & 0.015 & 0.020 \\
Benefit coverage & 0.131 & -0.119 & 0.367 & 0.069 & 0.048 & 0.243 \\
Minimum wage & 0.455 & -0.088 & 0.109 & 0.038 & 0.001 & 0.018 \\
Product market reg. & 0.137 & -0.050 & 0.149 & 0.056 & 0.011 & 0.081 \\
EPL regular & 0.999 & 2.521 & 0.445 & 0.945 & 1.737 & 0.654 \\
EPL temporary & 0.999 & -0.830 & 0.159 & 0.808 & -0.474 & 0.288 \\
Demography & 0.993 & 0.417 & 0.110 & 0.999 & 0.824 & 0.121 \\
Education & 0.999 & -0.104 & 0.021 & 0.567 & -0.040 & 0.041 \\
\hline
\end{tabular}

The dependent variable is the total unemployment rate for either males or females. The shock variables (labor demand shock, productivity shock, real import price shock and the interest rate) as well as the credit constraints are included in each regression. We use an unbalanced panel for 17 countries from 1982 to 2005 and control for country-and time-specific fixed effects. 
Table 5: Results for male and female youth unemployment

Prior incl. probab.

male

female

\begin{tabular}{lccc|ccc}
\hline Variable & $\begin{array}{c}\text { Posterior } \\
\text { inclusion } \\
\text { probabil- } \\
\text { ity }\end{array}$ & $\begin{array}{c}\text { Posterior } \\
\text { mean }\end{array}$ & $\begin{array}{c}\text { Posterior } \\
\text { standard } \\
\text { deviation }\end{array}$ & $\begin{array}{c}\text { Posterior } \\
\text { inclusion } \\
\text { probabil- } \\
\text { ity } \\
(1)\end{array}$ & $\begin{array}{c}\text { (2) } \\
\text { Posterior } \\
\text { mean }\end{array}$ & $\begin{array}{c}\text { Posterior } \\
\text { standard } \\
\text { deviation }\end{array}$ \\
& 0.999 & 0.514 & 0.084 & 0.999 & 0.562 & 0.083 \\
Payroll tax & 0.107 & -0.020 & 0.072 & 0.121 & 0.024 & 0.078 \\
Income tax & 0.999 & -0.553 & 0.098 & 0.999 & -0.661 & 0.097 \\
Consumption tax & 0.999 & 0.151 & 0.033 & 0.999 & 0.176 & 0.034 \\
Union coverage & 0.217 & -0.104 & 0.228 & 0.331 & -0.185 & 0.299 \\
Bargaining coord. & 0.038 & 0.000 & 0.013 & 0.047 & -0.002 & 0.017 \\
Union density & 0.167 & 0.007 & 0.019 & 0.085 & 0.003 & 0.012 \\
First year benefits & 0.055 & -0.050 & 0.320 & 0.061 & 0.065 & 0.365 \\
Benefit coverage & 0.066 & -0.011 & 0.056 & 0.046 & 0.005 & 0.040 \\
Minimum wage & 0.082 & -0.044 & 0.192 & 0.043 & -0.009 & 0.104 \\
Product market reg. & 0.999 & 5.797 & 0.854 & 0.999 & 5.541 & 0.880 \\
EPL regular & 0.999 & -1.469 & 0.297 & 0.961 & -0.996 & 0.345 \\
EPL temporary & 0.992 & 0.795 & 0.211 & 0.999 & 1.244 & 0.204 \\
Demography & 0.992 & -0.160 & 0.043 & 0.060 & -0.002 & 0.014 \\
Education & & & & & \\
\end{tabular}

The dependent variable is the youth unemployment rate for either males or females. The shock variables (labor demand shock, productivity shock, real import price shock and the interest rate) as well as the credit constraints are included in each regression. We use an unbalanced panel for 17 countries from 1982 to 2005 and control for country-and time-specific fixed effects. 
Table 6: Results for male and female 25+ unemployment

Prior incl. probab.

male

female

\begin{tabular}{lccc|ccc}
\hline Variable & $\begin{array}{c}\text { Posterior } \\
\text { inclusion } \\
\text { probabil- } \\
\text { ity }\end{array}$ & $\begin{array}{c}\text { Posterior } \\
\text { mean }\end{array}$ & $\begin{array}{c}\text { Posterior } \\
\text { standard } \\
\text { deviation }\end{array}$ & $\begin{array}{c}\text { Posterior } \\
\text { inclusion } \\
\text { probabil- } \\
\text { ity } \\
(1)\end{array}$ & $\begin{array}{c}\text { Posterior } \\
\text { mean }\end{array}$ & $\begin{array}{c}\text { Posterior } \\
\text { standard } \\
\text { deviation }\end{array}$ \\
& 0.999 & 0.205 & 0.040 & 0.970 & 0.177 & 0.058 \\
Payroll tax & 0.083 & -0.006 & 0.026 & 0.992 & 0.291 & 0.077 \\
Income tax & 0.993 & -0.182 & 0.047 & 0.954 & -0.198 & 0.072 \\
Consumption tax & 0.853 & 0.049 & 0.026 & 0.601 & 0.032 & 0.030 \\
Union coverage & 0.990 & -0.432 & 0.119 & 0.998 & -0.602 & 0.138 \\
Bargaining coord. & 0.374 & 0.027 & 0.041 & 0.138 & 0.008 & 0.025 \\
Union density & 0.999 & 0.050 & 0.011 & 0.903 & 0.043 & 0.020 \\
First year benefits & 0.119 & -0.091 & 0.300 & 0.059 & 0.033 & 0.198 \\
Benefit coverage & 0.910 & -0.203 & 0.091 & 0.058 & -0.005 & 0.028 \\
Minimum wage & 0.078 & -0.018 & 0.081 & 0.177 & 0.081 & 0.205 \\
Product market reg. & 0.986 & 1.499 & 0.433 & 0.452 & -0.571 & 0.713 \\
EPL regular & 0.999 & -0.751 & 0.132 & 0.573 & -0.275 & 0.280 \\
EPL temporary & 0.954 & 0.302 & 0.110 & 0.999 & 0.789 & 0.114 \\
Demography & 0.999 & -0.123 & 0.018 & 0.999 & -0.128 & 0.025 \\
Education & & & & & \\
\end{tabular}

The dependent variable is the adult unemployment rate for either males or females. The shock variables (labor demand shock, productivity shock, real import price shock and the interest rate) as well as the credit constraints are included in each regression. We use an unbalanced panel for 17 countries from 1982 to 2005 and control for country-and time-specific fixed effects. 